\title{
ÍNDIOS COMUNISTAS?
}

\author{
representações sociais dos imigrantes venezuelanos na cidade brasileira de Pacaraima
}

\section{COMMUNIST INDIANS?}

social representations of Venezuelan immigrants in the Brazilian city of Pacaraima

Ricardo Cortez Lopes ${ }^{1}$

(rshicardo@hotmail.com)

\begin{abstract}
RESUMO
Este trabalho busca analisar as representações sociais do imigrante venezuelano recente no Brasil para internautas à luz da crise imigratória do ano de 2018, principalmente no que se refere à ressignificação da ideia marxista de comunismo. Nosso material de análise foram comentários postados em sites de notícias e em redes sociais sobre os acontecimentos, buscando no momento de acirramento de ânimos as representações - segundo a perspectiva de Serge Moscovici - que estão subsumidas no cotidiano e emergem diante de estímulos como o da migração massiva. A análise indicou que a situação política do país de origem - cujas valorações são muito variadas - influi na construção de sua representação.
\end{abstract}

Palavras-chave: Venezuelanos. Imigração. Representações sociais.

\begin{abstract}
This paper aims to analyze the social representations of the recent Venezuelan immigrants to Brazil for internauts, in light of the immigration crisis of 2018, mainly in regards to the Marxist idea of communism. Our analysis material consisted of comments posted on news sites and social networks about the events, which we searched in a moment of, stirred up representations - according to the perspective of Serge Moscovici - that are subsumed in day-to-day life and emerge with stimuli such as massive migration. The analysis indicated that the political situation of the country - whose valuations are very varied - influences the construction of its representation.
\end{abstract}

Keywords: Venezuelan. Immigration. Social representations.

\section{INTRODUÇÃO}

Quando se fala em marxismo, podemos realizar uma extensa discussão teórica sobre o

\footnotetext{
${ }^{1}$ Doutorando em Sociologia pela Universidade Federal do Rio Grande do Sul (UFRGS).

CV Lattes: http://lattes.cnpq.br/0168878682156505.
} 
mesmo, elencando uma infinidade de autores e tradições. Neste artigo, pretendemos abordar não diretamente autores que partiram de Karl Marx, mas sim de uma interpretação (e mobilização) dada à teoria marxista, através da categoria comunismo, em um caso específico: a migração de venezuelanos para uma cidade brasileira, momento que criou muitas tensões no local.

É importante ressaltar que esse movimento é possível porque o marxismo, além de teoria, é também uma filosofia da práxis:

Para a concepção orgânica, elaborada por Karl Marx, a teoria não pode ser pensada de forma desligada da prática. Em frase que se tornou célebre, este autor afirmava que "os filósofos até hoje se contentaram em contemplar a realidade, mas o que importa é transformá-la". Desta forma, Marx afirma um vínculo indissolúvel entre teoria e prática, ação e reflexão, ciência e política, pensamento e realidade. (SELL, 2010, p. 105)

Essa é uma concepção forte especialmente para militantes marxistas, o que os incentiva a acelerar a tomada de poder por parte do proletariado para chegar ao comunismo (PETRY, 2014), quando os conflitos de classe desapareceriam por completo. Mas o que viria a ser o comunismo?

O comunismo é então um movimento político que surge com a Revolução Russa e que se espalha por todo o mundo, possuindo como base teórica o corpo teórico do marxismo-leninismo [...]. Para Marx, a sociedade comunista é o último estágio da história da humanidade. Nela não existirão mais exploradores e explorados, isto é, não existiriam mais classes sociais, e a figura do Estado iria desaparecer. Mas esse estágio só seria atingido após a tomada do poder pela classe operária, após a extinção do modo de produção capitalista, e após o advento do modo de produção socialista [...]. O que o comunismo quer, então, é fazer com que os meios de produção passem a ser de todos, comuns. No momento em que não houver mais meios de produção privados, consequentemente não haverá mais classes. (GUARESCHI, 1984, p. 47)

Assim, o comunismo é um horizonte (inevitável) vislumbrado por Marx, e deve ser obrigatoriamente precedido pelo socialismo; ou seja, a dialética marxista estaria voltada para superar a alienação que oculta a luta de classes a fim de que a classe explorada pudesse começar uma ditadura - essa ditadura que conduziria ao igualitarismo total, no qual o Estado não existiria.

Dessa mirada, podemos também observar como tal teoria é mobilizada pelos grupos que a utilizam; o que falta, ainda, é olhar representações sobre o 
comunismo e o marxismo não apenas como teorias, mas também como personalização dos sujeitos. Esse é o objetivo deste estudo: ver em que medida uma concepção do marxismo (comunismo) modula percepções, cotejada com outras interseccionalidades, como a étnica (FOUCAULT, 1997).

Este texto busca abordar o fenômeno da migração venezuelana para o Brasil através da cidade de Pacaraima, que, apesar de não ser o destino final desses indivíduos, é o que tem ganhado maiores atenções da esfera pública tupiniquim. $\mathrm{O}$ fenômeno não será investigado através de documentação ou retratado em sua complexidade intestina: o que pretendemos investigar é a faceta da apreciação por terceiros que não estão diretamente no local dos conflitos, mas que constroem representações sociais da mesma maneira. Assim, pretendemos entender a ressignificação de uma representação que já existe - a do cidadão venezuelano através do movimento de imigração, momento em que o passado, "passado", e o presente, "presente", redirecionam uma trajetória de vida e influem no processo de adaptação ao novo contexto.

Atualmente, o Brasil é rota de muitos imigrantes secundários (RODRIGUES, 2006), como os haitianos, que adentram o território para um trânsito geográfico que se quer definitivo. Uma das migrações mais polêmicas é a venezuelana para a cidade de Pacaraima, no estado de Roraima. Essa controvérsia pública reverbera tanto do ponto de vista cultural - a imagem que se faz do venezuelano - quanto do econômico - a condição de crise do sistema econômico brasileiro (FERNANDES, 2015) -, sem esquecer as dimensões políticas e as questões sanitárias (TOLEDO; KNAPP, 2016). Existe, também, outro fator importante nessa questão: o de segurança pública, que, somado a problemas de gestão pública já antigos, tem resultado no que alguns especialistas têm denominado como crise migratória (VIDIGAL; BRANDÃO; OLIVEIRA, 2018). Cumpre ressaltar que esse trânsito tem ocorrido desde 2015 (FÉLIX; COSTA, 2018) com cidadãos de etnias indígenas venezuelanas, porém o quadro se acelerou nos últimos meses. Migrantes têm ficado em abrigos ou acampamentos (BRAZILIENSE, 2018).

Sobre o assunto migração e Venezuela, Uebel (2018) problematiza a cobertura da imprensa tradicional, enquanto Cervo (2003) o faz através de cientistas brasileiros. Pretendemos agora empreender em outro campo: o resultado dessa comunicação de acontecimentos nas representações sociais do usuário que interage.

Já de saída, é possível observar que o governo municipal pede, judicialmente, pelo controle das fronteiras, e o governo federal aparentemente as 
abre (VIDIGAL; BRANDÃO; OLIVEIRA, 2018), o que já resultou em reclamações por parte de servidores do município (PRADO; MELLO, 2018). Na esfera civil, tem havido conflitos entre os moradores locais e os imigrantes, o que resultou em venezuelanos abandonando o país - no dia 19 de agosto, houve uma perseguição a refugiados e a queima de suas barracas e de seus pertences, por conta de um assalto a um comerciante brasileiro (PRADO; MELLO, 2018). Todos esses acontecimentos mudam uma representação prévia, mas sua identificação só é possível através de uma metodologia adequada.

\section{ABORDAGEM METODOLÓGICA E TEÓRICA}

Foi realizada, em um primeiro momento, a revisão bibliográfica para contextualizar o objeto; em continuidade, foram selecionadas páginas que noticiam ocorrências policiais com a migração, com o objetivo de realizar a leitura flutuante (BARDIN, 1997) dos 15 comentários selecionados; após esse momento, foi realizada a criação das categorias a posteriori. Com a posse dessas categorias, foi executada sua condensação em um instrumento de análise, para dele retirar os dados, no cotejo com o corpus coletado. Por fim, foi realizada a reconstrução da representação, na qual o componente marxista aparece.

O aporte teórico que sustenta o estudo é a teoria das representações sociais, as quais modulam o fenômeno a ser estudado. Sua concepção se deu a partir da obra de Serge Moscovici, que as concebe como entidades quase tangíveis que leem a realidade e a transformam em algo inteligível para o cognoscente. Assim, as ações do imigrante servem para classificar entidades - ideias e indivíduos - e criar hierarquias sociais valorativas, as quais são explicadas ou estranhadas justamente a partir das representações sociais que circulam e conferem parâmetros mais ou menos fixos.

É válido ressaltar que, como se trata de uma forma, a teoria das representações dá suporte para uma miríade de conteúdos. Assim, a migração pode, em um primeiro momento, ser objeto de uma revisão histórica:

Após a leitura de muitas pesquisas sobre a história das migrações, podemos pensar a respeito dos indícios das primeiras formas de processo migratório desde os tempos mais distantes. Alguns teóricos pensam que a evolução do Homo sapiens ocorreu na África, onde se acredita que tenha se desenvolvido e, tardiamente, o Homo sapiens migrara para outras regiões, chegando finalmente nas Américas. Em seus estudos, Marinucci e Milesi (2003) expõem os acontecimentos dos 
primeiros povoamentos no continente americano, em que os autores destacam que foram realizados por povos vindos de outras regiões, como da Austrália, da Malásia e da Polinésia. Assim, a história das migrações faz parte da própria história da formação de muitos países [...]. Para muitos autores, esta disposição sofreu transformações com as duas Guerras Mundiais, pois houve retrocessos na questão da mobilidade humana. Já na Primeira Guerra (1914-1919), vários países passaram a restringir a circulação de pessoas por razões ideológicas e políticas. E a Segunda Guerra Mundial trouxe consequências como um grande contingente de exprisioneiros e refugiados, que foram impedidos de voltar ao seu país. Outras consequências das duas grandes guerras foram que os países mais pobres passaram a apresentar um maior deslocamento de imigrantes, a fim de buscar melhores condições de vida, aos países ditos desenvolvidos. (GUILHERME, 2015, p. 14-15)

Assim, é importante delimitar o que é a migração, o trânsito temporal, espacial e social (VASCONCELOS, 2013), pois os transeuntes precisam viver o novo ambiente com as lembranças do outro lugar (CLIFFORD, 1994). Podemos começar pela questão de se ela é realizada por vontade individual. Se a resposta for sim, este pode ser caracterizado como migrante econômico - que busca outras condições de subsistência - ou humanitário - que está exercendo um papel de assistência social.

Se a resposta for que não existe a vontade individual, então é possível que isso aconteça por motivos políticos - o que dá origem a um refugiado - ou ambientais - por conta de desastres naturais -, ou por escravidão (GUILHERME, 2015). Ainda existem deslocamentos que se dão para fins turísticos, ou viagens curtas para negócios ou para estudo - o que não implica a reorganização da vida em um novo espaço e não é um ato considerado migratório (VASCONCELOS, 2013). Quanto aos locais de partida e o de chegada, estes resultam nas seguintes classificações: o emigrante é aquele que sai, o imigrante, aquele que chega (GUILHERME, 2015).

Um conceito vital que dá a tônica da crise diplomática é o de refugiado, estabelecido pela primeira vez na Convenção de Genebra, em 1951: "refugiados estão fora do seu país de origem devido a fundados temores de perseguição relacionados a sua raça, religião, nacionalidade, grupo social ou opinião política” (BRACAGIOLI, 2018, p. 10). Os países latino-americanos se baseiam na Declaração de Cartagena, de 1984, que amplia um pouco o espectro - o Brasil chegou a criar um Estatuto do Refugiado (BRACAGIOLI, 2018). Isso alimenta a polêmica: seriam os venezuelanos refugiados ou não? Tal questão causa muito conflito, porque o Brasil sempre foi um país de migração. 


\section{O BRASIL E A RECEPÇÃO}

É importante ressaltar que o Brasil sempre foi um país de fluxo, o que aconteceu, em um primeiro momento, por sua condição de colônia portuguesa. Assim, os ameríndios do território pré-colombiano já receberam migrantes lusitanos, que também trouxeram os escravos posteriormente:

Acerca das migrações, não podemos esquecer em citar as Grandes Navegações, que é sabido que foram as responsáveis pela colonização das Américas a partir do século XVI, e em que se iniciou uma grande união de culturas (europeia e indígena). De acordo com Bivar (2008), no Brasil, com esse fenômeno, chegaram os primeiros imigrantes reconhecidos, os portugueses, que trouxeram suas tradições, algumas das quais são mantidas até hoje, além do famoso sistema colonial. Quanto a esse sistema, a autora afirma que a partir dele o tráfico negreiro foi impulsionado, e trouxe outros imigrantes, os escravos africanos, mas estes foram tratados como simples mercadorias e foram trazidos de forma forçada. O Brasil, portanto, recebeu milhões de escravos e de escravas africanas, que foram muito importantes para a formação do nosso país. (GUILHERME, 2015, p. 14)

Outro momento importante foi a interiorização da metrópole pela Família Real Portuguesa, na expressão de Maria Ondina:

Além do que sublinhamos, podemos pensar na Abertura dos Portos (1808) às chamadas nações amigas como um marco importante no histórico das imigrações no território brasileiro, pois esse ato favoreceu a vinda de estrangeiros ao país. Assim, na visão de Bivar (2008), o encontro de diversas nacionalidades tornou a população mais complexa, principalmente em São Paulo, pela integração de muitas etnias. E, dessa forma, como delineia a mesma autora em seu livro, o século XIX é caracterizado pela presença de diversos imigrantes, como por exemplo portugueses, africanos, franceses, alemães, prussianos, italianos, espanhóis. Mas não podemos generalizar as causas das migrações, uma vez que os motivos para a vinda desses imigrantes podem ter sido diversos, por motivos econômicos, ou em função dos conflitos em seus países, ou de algum tipo de perseguição sofrida etc. (GUILHERME, 2015, p. 15)

Mas é possível afirmar que os grupos de maior expressividade em termos de população aportaram justamente para substituir a mão de obra escrava:

Depois disso, até final da década de 1950, em que o Brasil buscava mão de obra devido à abolição da escravidão, a migração predominante no país foi europeia, principalmente de alemães, italianos e portugueses e, em menor número, de asiáticos, como japoneses, turcos e libaneses. Ademais da mão de obra, podemos dizer que 
este tipo de migração foi uma política estatal para clarear a população, foi um projeto de branqueamento. (GUILHERME, 2015, p. 50)

É importante ressaltar que há uma particularidade no caso que estamos estudando: “O Brasil funcionou como país receptor de imigrantes até a década de 1960, para, a partir daí, passar a exportar mão-de-obra principalmente para os Estados Unidos, alguns países da Europa e para o Japão" (RODRIGUES, 2006, p. 198). Todavia, juntamente à dispersão ocorreu também uma recepção:

No início do século XXI, os imigrantes no Brasil ainda são, em sua maioria, latino-americanos e, agora, com um grande contingente de colombianos e mexicanos [...]. Porém, um novo coletivo migratório começa a aparecer expressivamente, composto por, majoritariamente, caribenhos, africanos e sul-asiáticos. (GUILHERME, 2017, p. 12)

Por essa razão é interessante a situação na fronteira com a Venezuela: nela está se colocando uma tensão oriunda da já tradicional imigração latino-americana. Mas parece haver outros elementos que tornam o ambiente mais conturbado, e nossa hipótese inicial era a de que a representação remeteria à semântica do índio; no entanto, esta acabou se aproximando da categoria política comunismo. Assim, a representação ressalta essas duas identidades, por vezes as mesclando ou criando um conflito entre elas. Mas há ainda um quarto elemento a ser explorado, o país de origem.

\section{VENEZUELA E DISPERSÃO}

A Venezuela, assim como o Brasil, foi uma colônia ibérica, porém de estirpe espanhola, que iniciou sua trajetória no ano de 1520 - ou seja, boa parte de sua história se desenrolou na instabilidade do fluxo colonial, o que se ressalta pelas constantes mudanças de fronteira, como as incorporações com a Grã-Colômbia, composta também pelo Equador.

Fora a origem multicultural já na colonização, a Venezuela também foi receptora legal de migrantes:

A Venezuela alternou esse papel de receptor nas décadas de 1950 e de 1970 a 1990, com uma redução de imigração internacional nos anos 1960. Os estrangeiros em 1950 representavam $4,1 \%$ da população total da Venezuela. Em 1971, representavam 5,5\%. Em 1980, eram 7,4\%. Em 1990, totalizavam 5,7\% dos 
imigrantes e, desses, $70 \%$ eram oriundos da América Latina e do Caribe, em especial da Colômbia, representando $51,7 \%$ do total de estrangeiros, seguidos de peruanos, equatorianos, bolivianos, dominicanos, guianenses e haitianos (Sarmento, 2000, p. 30). Nessa mesma década, os brasileiros representavam apenas $0,63 \%$ dos latinos americanos e $0,41 \%$ do total de estrangeiros na Venezuela (Baeningen, 2002). Pode-se afirmar que, de uma maneira geral, a Venezuela não é o destino prioritário para os emigrantes brasileiros, que preferem Paraguai, Uruguai, Argentina, Guiana Francesa, Suriname, Bolívia. (RODRIGUES, 2006, p. 198)

O artigo é de 2006, porém já aponta dados no mínimo curiosos. Atualmente o país se encontra em uma crise econômica, semelhantemente ao próprio Brasil. Os motivos dessa crise não são facilmente contextualizáveis, pois muito do material provém de pesquisadores que desejam mostrar o sucesso ou o fracasso do comunismo, o que torna a coleta de seus dados suspeita - trata-se do oposto da prática científica, que não coloca a interpretação à frente dos dados. Optamos, portanto, por apenas apontar que existe uma crise a qual independe da forte produção petrolífera, em uma visão "petroleocêntrica", o que talvez ajude a explicar parte da crise:

Contudo, [a Venezuela] padece de outro sério problema estrutural que decorre de ter ela uma das maiores economias petroleiras do mundo, e isto lhe dá um significado econômico específico, além do decorrente de sua abertura neoliberal. Refiro-me, brevemente, sobre o paradoxo fiscal e cambial que se manifesta em economias como esta, que têm o petróleo exportador como atividade predominante e dele extraem alta carga fiscal. Aqui, a renda de todo o setor petroleiro perfaz cerca de $28 \%$ do PIB total; a refinação representa cerca de $25 \%$ do produto da indústria de transformação; suas exportações representavam mais de $90 \%$ do total exportado nos anos setenta, pouco mais de $80 \%$ na década seguinte e de $70 \%$ a $75 \%$ na média 1990-99; sua contribuição para a receita fiscal total do governo central situou-se em torno de $80 \%$ até fins da década de 1980 , e entre $60 \%$ e $70 \%$ na de noventa. Por outro lado, embora diretamente perfaça "apenas" $28 \%$ do $\mathrm{PIB}$, seu enorme peso no setor externo e na receita fiscal condiciona fração muito maior do que essa na vida nacional, dado o elevado coeficiente de abertura do setor não petroleiro e do impacto do gasto público. (CERVO, 2003, p. 185)

Assim, é possível apreciar um pouco a série histórica da economia venezuelana com base nesse princípio:

A Venezuela vem revelando uma economia com características bastante diferenciadas dos demais países latino-americanos, já que, tendo se beneficiado dos grandes aumentos nos preços do petróleo nos anos 70 e 80, não fez parte do amplo grupo de países em desenvolvimento que se viram forçados ao endividamento internacional na ocasião; livrando-se assim do estrangulamento 
externo que paralisou as economias devedoras e provocou a moratória internacional, desaguando nos acordos voltados para o ajuste do balanço de pagamentos e renegociação da dívida externa da primeira metade da década de 80. Dadas tais circunstâncias favoráveis, pôde a Venezuela manter em quase todos os anos das décadas de 70 e 80 invejáveis taxas de crescimento econômico, ressalvados apenas os triênios 1976/78 e 1986/88, quando o PIB foi negativo ou pouco cresceu. (CERVO, 2003, p. 259)

Portanto, a alta na inflação é um problema recente, dado que houve uma diferenciação em relação a outros países latino-americanos:

A Venezuela tem se defrontado, nos últimos vinte e cinco anos, com essa "volatilidade" fiscal, com a inflação e com as alterações dos preços relativos. A não desvalorização nominal do câmbio na década de 1970 não foi fruto de uma decisão política e sim da maior inflação norte-americana em relação à do país, notadamente entre 1973 e 1978. Com isso, a economia teve dois efeitos contidos: a inflação mantida em níveis baixos (4\% anuais no primeiro quinquênio e 9\% no segundo) e a receita fiscal (real) petroleira aumentada, impulsionando a carga fiscal total de $22 \%$ do PIB em 1970-73 para $38 \%$ em 1974-75, permanecendo em $26,5 \%$ na média de 1978-79. Isto não só permitiu a expansão do gasto público (crescendo o investimento público à média anual de $22 \%$ na década), como também, via expansão do financiamento público, fez o investimento privado crescer à taxa anual de $15 \%$. O PIB cresceu à taxa média anual de 4,5\% em 1970-80 $(6,1 \%$ em 1971-77), desacelerando fortemente em 1977-79 (média de 2\%). (CERVO, 2003, p. 186)

Enfrentando crise ou não, podemos observar que a migração do povo venezuelano é uma característica quase cultural. Desde 2006 já tem ocorrido trânsito não migratório:

Hoje, os venezuelanos também transitam freneticamente nessa fronteira com vistas à aquisição de bens e utilização de serviços, como o de saúde e educação. Dessa forma, vários comerciantes, em maioria cearense, abriram filiais de suas matrizes de Boa Vista em Pacaraima, onde conseguiram retomar o aquecimento da economia do Estado. Portanto, esse crescimento econômico influenciou o processo migratório para Pacaraima e depois para Santa Elena do Uairén. (RODRIGUES, 2006, p. 198)

Apontado esse fluxo contínuo, podemos nos deter um pouco em suas peculiaridades. Isso porque há um cruzamento das trajetórias desses países através das vivências dos imigrantes, que trazem suas representações de outsiders e as contrastam com as dos estabelecidos. 


\section{O CRUZAMENTO DAS TRAJETÓRIAS NO IMIGRANTE: PACARAIMA}

No ano de 2006, o objetivo principal dos migrantes que se colocavam em fluxo parecia ser o de buscar uma ascensão social, como relata Rodrigues (2006, p. 198):

Esse quadro se modifica na fronteira entre Brasil e Venezuela, tendo em vista que a emigração fronteiriça é uma possibilidade viável de ascensão social para o grande contingente de migrantes interestaduais e, também, pelas condições de proximidade e facilidade de acesso via terrestre. Vale lembrar que a capital da unidade da federação mais próxima a Boa Vista, Manaus, fica a quase oitocentos quilômetros de distância, enquanto a fronteira com a Venezuela fica a menos de duzentos quilômetros.

Atualmente, no entanto, alguns venezuelanos entrevistados por jornalistas afirmaram que há pobreza extrema, porém esta não é acompanhada pela fome. É importante ressaltar que existem similitudes entre o lugar de saída e o de chegada - eles não são contextos completamente heterogêneos:

O Estado Bolívar ao sul da Venezuela e o Estado de Roraima na Região Norte do Brasil possuem similitudes, tais como o fato de se constituírem em grandes espaços em relação aos seus respectivos territórios nacionais; viverem processos de expansão da fronteira econômica, cujos programas oficiais de exploração de recursos naturais enfatizavam o caráter de "espaços vazios", culminando com políticas de ocupação baseadas no conceito de desenvolvimento vinculado à doutrina de Segurança Nacional; são palcos de constantes conflitos pelo controle dos recursos naturais travados por diversos atores sociais (índios, garimpeiros, madeireiros, empresários, fazendeiros, militares); possuem populações indígenas significativas e estão situados em áreas de fronteira internacional; portanto, em área que delimita a soberania das duas nações. (RODRIGUES, 2006, p. 198)

Ou seja, já existia, muito antes de 2015, uma migração natural de ambos os lados, o que faz disso uma característica do espaço geográfico. Os indivíduos desse local são considerados fronteiriços:

Esse lugar fronteiriço Pacaraima-Santa Elena do Uairén encerra uma caracterização de relações e movimentos de pessoas que transitam, deslocam-se e, consequentemente, definem o lugar a partir dos efeitos produzidos e conteúdos expressos, tanto nos aspectos da vida cultural quanto nos aspectos identitários que também se deslocam e se pluralizam (Hall, 2003). Esses sujeitos que vivem a e na fronteira podem ser classificados em categorias como fronteiriços, aqueles nascidos nessa zona de fronteira; os fronteiriços nacionais migrantes, que são os provenientes de outras regiões do país; e os fronteiriços 
internacionais migrantes, que incluem todos os estrangeiros (Marcano, 1996). Acrescentaria os viajantes, aqueles que fazem da fronteira um lugar de trânsito, de cruzamento diário por motivos laborais, de diversão e lazer. (RODRIGUES, 2006, p. 198)

Essa situação de espelhamento talvez faça com que os indivíduos não se sintam verdadeiramente em trânsito e não compreendam o local de recepção como um contexto completamente diferente daquele em que foram sociabilizados. Todavia, os desdobramentos violentos talvez tenham dado essa sensação para quem observa de fora - é o que vamos investigar com a amostra.

\section{ELEMENTOS E REPRESENTAÇÃO}

Nesta seção, apresentaremos os resultados do estudo empreendido, que consistiu em confrontar os dados empíricos com o referencial teórico que coligimos. A estrutura deste tópico foi baseada em categorias, como ficará claro no decorrer do texto. Também é importante ressaltar que os comentários foram retirados da internet, e mantidos seus erros de digitação. A seguir (Tabela 1), mostramos os títulos dos artigos comentados:

Tabela 1: Títulos e URLs dos artigos

\begin{tabular}{|c|c|}
\hline Títulos & URLs \\
\hline $\begin{array}{l}\text { Com invasão venezuelana, Roraima teme } \\
\text { retorno de doenças erradicadas }\end{array}$ & $\begin{array}{l}\text { https://www1.folha.uol.com.br/mundo/2016/11/1833819- } \\
\text { com-invasao-venezuelana-roraima-teme-retorno-de-doencas- } \\
\text { erradicadas.shtml }\end{array}$ \\
\hline $\begin{array}{l}\text { Após ataques de brasileiros, } 1,2 \text { mil } \\
\text { venezuelanos deixaram o país, diz Exército }\end{array}$ & $\begin{array}{l}\text { https://g1.globo.com/google/amp/g1.globo.com/rr/roraima/no } \\
\text { ticia/2018/08/19/pacaraima-tem-ruas-desertas-apos- } \\
\text { confronto-entre-brasileiros-e-venezuelanos.ghtml }\end{array}$ \\
\hline $\begin{array}{l}\text { Venezuela solicita ao Brasil proteção aos } \\
\text { imigrantes em Roraima }\end{array}$ & $\begin{array}{l}\text { https://www.correiobraziliense.com.br/app/noticia/brasil/201 } \\
\text { 8/08/19/interna-brasil,700829/venezuela-solicita-ao-brasil- } \\
\text { protecao-aos-imigrantes-em-roraima.shtml }\end{array}$ \\
\hline Comentário em rede social & $\begin{array}{l}\text { https://www.facebook.com/permalink.php?story_fbid=67497 } \\
\text { 4162869521\&id=100010708299705 }\end{array}$ \\
\hline
\end{tabular}




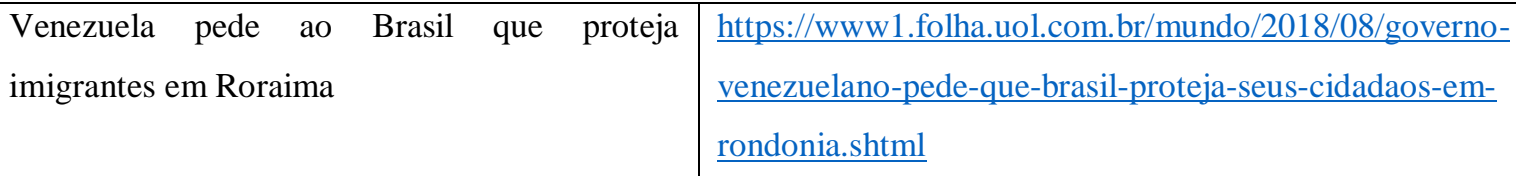

É importante afirmar que os títulos dão uma boa ideia do que é descrito, e soma-se a isso o fato de os artigos terem ajudado na contextualização do fenômeno nas seções anteriores. Assim, fomos diretamente para os comentários, ao invés de nos determos nas reportagens.

A primeira categoria tem a ver com a ilegalidade da situação. Foram encontradas muitas falas que remetiam ao candidato à presidência Jair Bolsonaro, às vezes com alusão ao muro que Donald Trump construiria para barrar imigrantes mexicanos nos Estados Unidos da América. Essa associação faria do venezuelano um aproveitador: "Nas próximas eleições Bolsonaro [sic] vai construir um muro [sic] para conter os imigrantes ilegais" (TOLEDO; KNAPP, 2016). Nesse caso, o comentador está associando toda uma constelação de ideias que se voltam ao fim do fluxo migratório, mesmo que a comparação tenha sido um tanto descontextualizada, já que o muro dos EUA estaria apenas na fronteira com o México.

Outras falas, no entanto, apontaram o oportunismo como oriundo do governo municipal. Este estaria buscando maior volume de verbas junto à União e, ao mesmo tempo, não saberia lidar com o crescimento populacional, situação impensável para um estado dessa região do Brasil:

Eu li bem: 1,8 mil pessoas? Só isso? Há um claro sensacionalismo nesta notícia. Não sei a quem interessa: a Imprensa do quanto pior melhor ou ao Governo de RR que busca plantar um problema para vender soluções milagrosas ou "urgentes" de olho no orçamento Federal ou mesmo, ainda, quem sabe, um desses "Estados de Emergências" que abriria muitas torneiras sem controle. Se Roraima, que precisa de mais gente, não consegue lidar com 1800 pessoas a mais, melhor fechar ou voltar a ser território. (TOLEDO; KNAPP, 2016)

Assim, o venezuelano aparece como potencial agente de incremento econômico, algo inviável nas condições normais: "Uma pena que os políticos [sic] aqui tenham falta de visão. Essa emigração na verdade poderia ser a melhor oportunidade de Roraima [sic] crescer neste século. Ou vocês conhecem algum brasileiro que deseja ardentemente ir para Roraima?" (COSTA; BRANDÃO; OLIVEIRA, 2018). Ou seja, seria possível povoar a região para um possível desenvolvimento econômico, o que torna o venezuelano uma solução para um problema contínuo, a escassez populacional. 
Outros comentários enfocam o governo venezuelano, que seria uma ditadura comunista (FRANCE-PRESSE, 2018); isso faz do imigrante alguém em busca da liberdade que lhe é negada: "Se o maduro [sic] está tão preocupado, porque ele não cuida de seus cidadãos [sic] que estão fugindo justamente dele que é a causa de tudo" (FRANCE-PRESSE, 2018). Nesta fala, podemos observar um destaque da figura pessoal de Maduro como causador individual da necessidade de migração.

Essa ideia de causalidade simples é generalizada para um espectro político específico: "A esquerda cada vez mais mostrando sua inutilidade" (FRANCE-PRESSE, 2018). A expressão "inutilidade" aponta para uma concepção de que a esquerda (que nem sempre é marxista) estaria completamente dissonante das necessidades políticas, ou seja, o problema se geraria da falta de competência mais do que propriamente de coerção autoritária. Nesse sentido, o venezuelano acaba sendo alguém que não aprova essa coerção: "Os venezuelanos não querem proteção em outro país. Eles querem ficar protegidos de ditadores [sic] que lhes quer a morte em seu próprio país” (FRANCE-PRESSE, 2018). E "O Brasil, EUA e outros países tem [sic] que intervir militarmente e tirar esse ditador comunista de lá na bala, tem muita gente morrendo pelo seu experimento comunista, se não intervirmos mais pessoas vão vir para o nosso pais [sic] que não tem nem pra nós" (COSTA; BRANDÃO; OLIVEIRA, 2018). Nesse caso, o comunismo é concebido como uma ditadura, o que vai de encontro com o pensamento marxista original, pois a ditadura seria a do socialismo e seria coletiva, e não individual - o que exclui a expressão “ditador". Também é utilizada a expressão "experimento", ideia oposta à concepção de finalização dada ao comunismo, enquanto cume de um processo anterior, o socialismo. Por fim, a fala corrobora parcialmente a concepção de Marx de que há uma alienação que esconde a possível solidariedade proletária: para além de não existir essa ajuda mútua, o comentador também solicita uma "intervenção militar", o que pararia o processo descrito e previsto por Marx.

Todos esses comentários caracterizam negativamente o governo venezuelano por seu caráter "esquerdista" ou "comunista". Mas há um comentário que associa essas categorias a algo bom:

Vejo muita gente boa de esquerda defendendo os venezuelanos contra o fascismo e a xenofobia dos brasileiros. Ora, os venezuelanos que estão imigrando também são fascistas. Se não fossem, ficavam em casa dando suporte ao Presidente Maduro, que tanto precisa de auxílio na luta contra o imperialismo e o capital estrangeiro. Essa briga entre reacionários venezuelanos e brasileiros não nos diz respeito. Eles que se lasquem. (FACEBOOK, 2018) 
Nesse caso, o "fascista" aparece como oposição direta à luta entre imperialismo e capital estrangeiro - as duas categorias que o comunismo planeja superar ao final: "o Estado iria desaparecer" (imperialismo), "exploradores e explorados" (capital estrangeiro). Assim, não é propriamente uma crítica, mas uma expansão das ideias marxistas originais, visto que Marx viveu em um contexto de predomínio do setor industrial e sua análise recai muito sobre essa atividade:

Com a revolução industrial, as forças produtivas provocam uma gigantesca transformação nas relações de produção. Surgem novas classes sociais: a burguesia e o proletariado. No modo de produção capitalista, a burguesia exerce diretamente o poder através do Estado Parlamentar e impõe sua visão individualista do mundo através das artes, da ciência, da filosofia e até da religião. (SELL, 2010, p. 84)

Assim, trata-se da mesma adjetivação; o que varia é sua positivação ou negativação enquanto valor de vida. E nisso o próprio movimento se torna significante de uma luta maior.

Outros comentários apontam a existência de contraventores que se aproveitam da migração ou que assumem a condição por causa das facilidades da imigração e de uma suposta fraca segurança pública brasileira, o que faz do venezuelano um povo variado: "tem gente que realmente precisa de ajuda, mas com certeza tem muitos bandidos VENEZUELANOS TRFICANTES [sic] DE DROGA. NESSE MEIO, AI É UM PROBLEMA SÉRIO [sic]” (FRANCE-PRESSE, 2018). Podemos observar que não há uma generalização do venezuelano em si, porém há uma inviabilização para o fluxo: a presença dos traficantes, que ganharam força no país original. Outra fala complementa esse ponto com uma questão de gestão: “O que esse cafajestedesse [sic] governo da Venezuela tem que fazer é criar vergonha e resolver seus problemas, esse vagabundo. o Brasil também aqui toda vida foi casa da mãe joana [sic], desde a colonização da canalha portuguesa, BOLSONARA [sic] NELES" (FRANCE-PRESSE, 2018). Ou seja, os dois governos não desempenham seu papel adequadamente, e isso abre brecha para transgressões da lei, o que torna os dois Estados próximos também nesse sentido. Porém, aparentemente, a situação da Venezuela seria pior, pois se trataria de um governo intencionalmente displicente ("vagabundo").

Outros fragmentos textuais reforçam que o Brasil já possui problemas internos, fazendo do Venezuelano um problema a mais (FRANCE-PRESSE, 2018; VENEZUELA, 2018; COSTA; BRANDÃO; OLIVEIRA, 2018): “Um país à beira da falência recebendo imigrantes de um país falido só podia dar nisso" 
(FRANCE-PRESSE, 2018). Trata-se, portanto, de uma análise que avalia também os acontecimentos recentes ao invés de emitir julgamentos diretamente, mas que atribuir a causalidade maior ao governo brasileiro, que não conseguiria lidar com a crise migratória: "Simples. Criar um território no lado venezuelano, O Brasil cuida e a ONU paga a conta" (FRANCE-PRESSE, 2018). Nesse caso, pode-se perceber uma associação direta com a Organização das Nações Unidas, porém não é possível saber se o comentador se refere a: (a) direitos humanos formulados pela UNESCO (em um sentido irônico), ou (b) atribuição de um papel de conciliação de conflitos internacionais (em um sentido literal). É possível cotejar essa fala com outra para tentar determinar um sentido:

Você tem razão, mas não acha que já temos problemas de sobra, aqui e que nem mesmos nós, estamos aguentando? Imagine, ter a casa assaltada por um bando deles; aqui já tem muito ladrão; os que estão no "poder" e os que estão nas "ruas" Acho que já ajudaram a muitos venezuelanos e ainda vem mais??? ¿Por qué no te callas, Maduro”? (FRANCE-PRESSE, 2018)

Nessas falas, podemos observar que há uma concepção do governo brasileiro como desprovido de bens econômicos (o tesouro nacional, no caso) e sem estabilidade moral - de modo que é reutilizada uma fala dirigida anteriormente a Hugo Chávez (1999-2013). Outra fala apontou o seguinte:

Exatamente, deem cobertura a eles para que possam seguir seu caminho de volta com tranquilidade. Os venezuelanos pertencem ao governo de lá, já temos problemas demais por aqui. Vir para cá só para aumentar os índices de violência, desemprego e mendicância? (VENEZUELA, 2018)

Nessa fala é colocado em perspectiva o governo venezuelano, que não cumpre com seu papel e, aparentemente, dá origem a "índices de violência, desemprego e mendicância".

Por fim, nossa hipótese foi refutada por encontrarmos apenas um comentário relacionado a indígenas: "O dia que eu virar índio vou pra lá” (COSTA; BRANDÃO; OLIVEIRA, 2018). Nesse caso, o autor parece estar se referindo à possibilidade de migração sem nenhuma normatização posterior, e a utilização de "virar índio" parece indicar que a situação é inacreditável. No entanto, o que obteve recorrência mais forte no material foi realmente a questão do comunismo como, primeiramente, associado à ditadura - para obliterar o eu -, e como disparador da emigração do país de origem. Assim, o comunismo, parte da teleologia marxista, aparece como conector causal para explicar atitudes; a imigração, por sua vez, aparece mais como um problema 
ideológico, percebido somente quando o sistema não consegue mais esconder a miséria. Tal discussão reforça a presença das tensões políticas de nossa época.

\section{CONSIDERAÇÕES FINAIS}

A conclusão preliminar é de que a representação social que emerge é a de um indivíduo potencialmente perigoso - por conta do regime do qual proveio, que ou o deixa ou com gana de liberdade, ou com propensão a cometer crimes -, mas que pode suprir uma demanda populacional se o governo decidir direcionar esforços. Podemos notar que, na maioria dos casos, poucas páginas possuem comentários, o que mostra certa indiferença do público em geral quanto ao assunto. Talvez isso ocorra porque a imigração decorre em um estado já representado como indígena, o que exclui algumas questões étnicas de pureza racial. Essa indiferença aponta para a possibilidade de estarmos lidando com um problema que será percebido em sua integralidade apenas quando atingir algum centro urbano; porém, só será possível afirmá-lo com certeza quando houver maior embasamento empírico.

Promovemos uma análise mais acurada dos dados sobre a crítica a um suposto comunismo para encaixar de forma mais natural o tema ao Dossiê Marx, já que se trata de uma análise das distorções históricas quanto ao tema conceitual em questão. Nesse sentido, há uma não compreensão completa do referencial teórico marxista: o comunismo aparece como uma maneira de manter a dominação estatal, ao invés de promover a suspensão do Estado, como no sentido original. Já o apoio ao comunismo vem acompanhado de uma "expansão" para uma época pós-industrial.

É interessante observar uma representação social não apenas se formando, mas se reconfigurando. Isso porque as representações sociais são baseadas em ancoragens anteriores, para daí produzirem seu efeito através da objetificação. No caso, as situações de crise podem evidenciar esses elementos escondidos pelo cotidiano, e a internet possibilita que eles se tornem documentáveis e, tal como evidências, possam ser discutidos entre os pares.

O objetivo deste texto não é o de conhecer esses sentimentos para direcionar a sociedade ao caminho desejado pelo analista. Não cabe a ele o papel de ditar como a sociedade deve se desenvolver, ainda mais através de lentes partidárias (sejam partidos de esquerda ou de direita). Percebemos isso quando fomos estudar a Venezuela: encontramos a mesma animosidade dos comentários da internet nos cientistas, 
porém com uma roupagem mais trabalhada. Assim, o construto teórico parece ter menos impacto do que o sistema político pensado a partir dele, e parece impossível manter-se indiferente.

Ressaltamos que não se trata de uma busca da neutralidade, o que é impossível. Tratase, sim, de conseguir pesar os prós e contras dos sistemas políticos e filosóficos de acordo com parâmetros bem especificados pelo analista, a fim de que seu viés fique claro e possibilite a contestação pelos pares. Isso porque o analista que tenta impor sua visão de mundo pode acabar encontrando o mesmo destino do personagem principal de $O$ alienista, de Machado de Assis: Simão Bacamarte, ao diagnosticar todos da cidade de Itaguaí como loucos, percebeu, através de suas ações, que o mais insano seria ele mesmo. 


\section{REFERÊNCIAS}

BARDIN, Laurence. Análise de conteúdo. Lisboa: Edições 70, 1977.

BRACAGIOLI, Samuel Bastos. Migrações internacionais contemporâneas em Porto Alegre: geografia escolar contra a xenofobia. 2018. 55f. Trabalho de Conclusão de Curso (graduação em Geografia). Instituto de Geografia. Porto Alegre, Universidade Federal do Rio Grande do Sul: 2018.

BRAZILIENSE, Correio. Conheça a saga dos venezuelanos que chegam ao Brasil em busca de dignidade. 2018.2 Disponível <https://www.correiobraziliense.com.br/app/noticia/brasil/2018/05/06/internabrasil,678654/amp.html >. Acesso em: 20 de agosto de 2018.

CERVO, Amado Luiz. Venezuela: visões brasileiras. Brasília: IPRI, 2003. Disponível em: <https://s3.amazonaws.com/academia.edu.documents/38625041/257Venezuela_Visoes_Brasileiras.pdf?AWSAccessKeyId=AKIAIWOWYYGZ2Y53UL3A\&Exp ires $=1535564074 \&$ Signature $=8$ FK5VW9WV3xxiYY\%2BHmI7RbbV5Lg\%3D\&responsecontent-disposition=inline \%3B\%20filename\%3D257-

Venezuela_Visoes_Brasileiras.pdf\#page $=157>$.

CLIFFORD, James. Cultural Anthropology. Further Inflections: Toward Ethnographies of the Future, v. 9, n. 3, p. 302-338, 1994.

COSTA, Emily; BRANDÃO, Inaê; OLIVEIRA, Valéria. Fuga da fome: como a chegada de 40 mil venezuelanos transformou Boa Vista. 2018. G1. Disponível em: <https://g1.globo.com/rr/roraima/noticia/fuga-da-fome-como-a-chegada-de-40-milvenezuelanos-transformou-boa-vista.ghtml>. Acesso em: 20 de agosto de 2018.

FACEBOOK. 2018.

Disponível em: <https://www.facebook.com/permalink.php?story_fbid=674974162869521\&id=10001070829 9705>. Acesso em: 27 de agosto de 2018.

FÉLIX, Jackson; COSTA, Emily. Após ataques de brasileiros, 1,2 mil venezuelanos deixaram o país, diz Exército. 2018. G1. Disponível em: < https://g1.globo.com/google/amp/g1.globo.com/rr/roraima/noticia/2018/08/19/pacaraimatem-ruas-desertas-apos-confronto-entre-brasileiros-e-venezuelanos.ghtml>. Acesso em $20 \mathrm{de}$ agosto de 2018 . 
FERNANDES, Felipe Lemos. (2016). Análise da gestão financeira dos Programas de Pós-Graduação da Universidade Federal do Rio Grande do Sul: um estudo sobre a alocação dos recursos de custeio e o corte orçamentário de 2015. Trabalho de conclusão de curso (Especialista em Administração Pública Contemporânea) - Universidade Federal do Rio Grande do Sul. Escola de Administração. Departamento de Ciências Administrativas, Porto Alegre.

FOUCAULT, Michel. Ethics, subjectivity and truth. In: RABINOW, Paul (Ed.). Essential works of Michel Foucault (1954-1984). New York: The New Press, 1997.

FRANCE-PRESSE, Agência. Venezuela solicita ao Brasil proteção aos imigrantes em Roraima. 2018.

Disponível em:

$<$ https://www.correiobraziliense.com.br/app/noticia/brasil/2018/08/19/interna-

brasil,700829/venezuela-solicita-ao-brasil-protecao-aos-imigrantes-em-roraima.shtml>.

Acesso em: 20 de agosto de 2018.

FUNDAÇÃO Getúlio Vargas. Entenda qual o perfil dos imigrantes venezuelanos que chegam ao Brasil. 2018. Disponível em: <http://dapp.fgv.br/entenda-qual-o-perfil-dosimigrantes-venezuelanos-que-chegam-ao-brasil/>. Acesso em: 20 de agosto de 2018.

GUARESCHI, Pedrinho Alcides. Sociologia crítica: alternativas da mudança. Porto Alegre: Mundo Jovem, 1984.

GUILHERME, Ana Julia. A migração como um direito e não como um problema: uma abordagem sociológica sobre o Fórum Permanente de Mobilidade Humana do Rio Grande do Sul. 2015. 55f. Trabalho de conclusão de curso (Graduação em Ciências Sociais) Instituto de Filosofia e Ciências Humanas. Porto Alegre: Universidade Federal do Rio Grande do Sul, 2015.

Imigrantes haitianos e senegaleses no Brasil: trajetórias e estratégias de trabalho na cidade de Porto Alegre. Dissertação (Mestrado) - Universidade Federal do Rio Grande do Sul. Instituto de Filosofia e Ciências Humanas. Programa de Pós-Graduação em Sociologia, Porto Alegre, 2017.

MOSCOVICI, Serge. A psicanálise, sua imagem e seu público. Petrópolis: Vozes, 2012.

PETRY, Almiro. Noções básicas de sociologia: a epistemologia e o pensamento dos clássicos. Porto Alegre: CirKula, 2014.

PRADO, Avener; MELLO, Patrícia Campos. Venezuelanos e brasileiros se confrontam nas ruas de cidade de Roraima. Folha de São Paulo. 2018. 
Disponível em: <https://www1.folha.uol.com.br/amp/mundo/2018/08/refugiadosvenezuelanos-sao-agredidos-e-expulsos-de-tendas-em-roraima.shtml>. Acesso em: 20 de agosto de 2018.

RODRIGUES, Francilene. Migração transfronteiriça na Venezuela. Estudos avançados, v. 20, n. 57, p. 197-207, 2006.

SELL, Carlos Eduardo. Clássicos da Sociologia: Marx, Durkheim e Weber. Petrópolis: Vozes, 2010.

TOLEDO, Marcelo; KNAPP, Eduarda. Com invasão venezuelana, Roraima teme retorno de doenças erradicadas. 2016. Folha de São Paulo. Acesso em: < https://www1.folha.uol.com.br/mundo/2016/11/1833819-com-invasao-venezuelana-roraimateme-retorno-de-doencas-erradicadas.shtml>. Acesso em 20 de agosto de 2018.

UEBEL, Roberto Rodolfo Georg; RANINCHESKI, Sonia Maria. "Polícia Federal deporta 450 imigrantes ilegais venezuelanos de Roraima": um estudo sobre remediation, positivismo e pós-positivismo no jornal O Globo. Diálogo, n. 37, p. 39-52, 2018.

VASCONCELOS, Iana dos Santos. Articulações familiares transnacionais: estratégias de cuidado e manutenção familiares na fronteira Brasil/Venezuela. 2013. 138f. Dissertação (Mestrado em Antropologia). Programa de Pós-Graduação em Antropologia. Boa Vista: Universidade Federal de Pernambuco, 2013.

VENEZUELA pede ao Brasil que proteja imigrantes em Roraima. 2018. Folha de São Paulo. Disponível em: <https://www1.folha.uol.com.br/mundo/2018/08/governovenezuelano-pede-que-brasil-proteja-seus-cidadaos-em-rondonia.shtml>. Acesso em 20 de agosto de 2018.

VIDIGAL, Lucas; BRANDÃO, Inaê; OLIVEIRA, Valéria. Crise na fronteira entre Brasil e Venezuela envolve colapso econômico e queda de braço judicial; entenda. G1. 2018. Disponível em:

<https://g1.globo.com/google/amp/g1.globo.com/mundo/noticia/2018/08/18/crise-nafronteira-entre-brasil-e-venezuela-envolve-colapso-economico-e-queda-de-braco-judicialentenda.ghtml>. Acesso em 20 de agosto de 2018. 